\title{
Critical Approaches to Education in the Work of Lorenzo Milani and Paulo Freire ${ }^{1}$
}

\begin{abstract}
Published as 'Critical Approaches to Education in the work of Lorenzo Milani and Paulo Freire' in Studies in Philosophy and Education, Vol. 26, No. 6, pp. 525-544. rights held by Springer.
\end{abstract}

\section{Peter Mayo \\ University of Malta}

Lorenzo Milani (1923-1967) and Paulo Freire (1921-1997) are widely regarded as two figures who can provide insights for a critical approach to education. Paulo Freire needs no introduction to an English speaking audience since he enjoys almost iconic status among educators, especially radical educators, worldwide. Milani, for his part, is certainly revered in Southern Europe, especially his native Italy, for his equally radical approach to education and schooling in particular. He has gained recognition in the English speaking world since some of the works he wrote (those concerning his trial and tribulations) and others with which he is strongly associated (Lettera a Una Professoressa-Letter to a Teacher) have been translated into English ${ }^{2}$ and have been the subject of some insightful discussions. The Lettera a Una Professoressa (henceforth the Lettera) has also been translated into Spanish and read in Freire's Latin America, albeit clandestinely in those countries that went through fascist dictatorial periods. ${ }^{3}$ Milani is less known than Freire in critical education circles and it is only recently that he has begun to be considered as a potential international contributor to that area known as critical pedagogy (Borg \& Mayo, 2006). This paper will highlight the common elements, as well as divergences, in both that can help educators adopt a critical approach to 
education, an approach that is predicated on social justice and that therefore signifies an option for the oppressed.

One would feel inclined to ask why bother to provide a comparative study of the ideas of these two figures. What is there to be had from such an exercise? My view is that despite the differences in geographical contexts and the periods in which they lived and worked, there is so much convergence between the two, including their democratic left leaning approach to education, not to mention the radical social justice-oriented religious influence felt in both, that they together provide nourishment for those seeking insights and pedagogical signposts for a truly social justice education. It is with this intention in mind that I engage in this comparative exercise, hoping to provide a brief attempt at a synthesis towards the end.

\section{Biographical accounts}

An account of the two biographies involved and their bearing on the ideas of Milani and Freire would be appropriate at this stage. This would also help readers locate the two figures geographically, historically and socially. One must recognise that the work in both cases denotes praxis, the concept that lies at the heart of Freire's philosophy and pedagogical approach and which dates back to at least the Ancient Greeks, and notably Aristotle. This is how Freire defines praxis in Pedagogy of the Oppressed.

But human activity consists of action and reflection: it is praxis, it is transformation of the world. Freire, 1993, p.125).

Freire goes on to say that the whole process involved can be enlightened through theory and he relates the whole process of action and reflection to theory and practice.(ibid.) The 'action-reflection-transformative action,' process is not sequential but dialectical (Allman, 1999, 2001). It is praxis that lies at the heart of Paulo Freire's 
notion of critical literacy. Freire and other intellectuals, with whom he has conversed in 'talking books', conceive of different learning situations in their life as forms of praxis. Milani and his students at Barbiana were not much different in this respect. These situations are viewed as moments when people can gain critical distance from the context they know to perceive it in a more critical light. Many of the ideas emerge from reflection on the two authors' world of action which therefore necessitates some consideration of their biographical trajectory. One cannot therefore isolate many of the ideas from the various experiences in Milani's and Freire's life history and that of the people with whom they worked. They are in many ways the embodiment of their own ideas. A biographical account of both is therefore necessary to help the reader contextualise the ideas that are brought to the fore later on in the essay. I will devote more space to Milani for two reasons. In the first place, an extensive literature on Freire's biography is available (e.g. Taylor, 1993; Roberts, 2001; Darder, 2002; Mayo, 2004). Second, Milani is the lesser known figure of the two.

\section{Paulo Freire (1921-1997)}

Paulo Reglus Neves Freire came from a relatively well to do family in Recife (state of Pernambuco) in the North East of Brazil but experienced hunger at the time of the Great Depression. It was a temporary experience but one which was strong enough to help develop strong feelings for the underprivileged in a region considered the poorest in Brazil. He fell behind at school because of his illnesses but gradually caught up and eventually read law at the University of Recife. His practice of law was very short-lived as a result of his compassion for a young dentist, starting out in his career, he was meant to charge on behalf of a client (Freire, 1994). The dentist's genuine account of how he 
had to incur debts to purchase the stipulated equipment for the practise of his profession touched Freire who realised the injustice of the legal system for the weak. On the encouragement of Elsa, his first wife, Freire subsequently took up teaching. He also wrote a doctoral dissertation in education which became his first book (Educação como pratica da Liberdade, see English version in Freire, 1973) and worked in the areas of adult education and specifically adult literacy in Brazil.

The most noteworthy aspect of his work was the ability to stress the link between education and politics and therefore to enable people to read not only the word but also the world. This approach, first adopted in Angicos, caught the attention of the Federal Minister of Education, Paulo de Tarso Santos, who invited Freire to discuss plans for a nationwide literacy campaign based on Freire's pedagogical approach. The campaign was at a concrete stage of planning in 1964 when a multinationals-backed military coup toppled the government led by João Goulart. ${ }^{4}$ Freire did not escape the wrath of the military regime that arrested him for what was considered to be a dangerous subversive literacy approach. Freire subsequently went into exile first in Bolivia and then Chile where, together with many other Brazilian exiles, he began to gain insights from Marxist writings in addition to those he had earlier derived from other sources, notably Christianity and Phenomenology. It is during this period that he worked in literacy programmes involving Chilean campesiños and wrote Pedagogia do Oprimido (Pedagogy of the Oppressed) which he could only publish in English when he had a stint at Harvard University before moving to Geneva to work for the World Council of Churches. The Geneva work brought him in contact with former Portuguese colonies in Africa (see Freire, 1978, Freire and Macedo, 1987 and Freire and Faundez, 1989) and 
workers from different parts of Europe. Freire returned to Brazil from exile in the early 1980s to 'relearn' his country and eventually became Education Secretary in São Paulo when the candidate representing the Partido dos Trabalhadores, which he helped found, was elected Mayor. ${ }^{5}$

\section{Lorenzo Milani (1923-1967) ${ }^{6}$}

Don Lorenzo Milani hailed from Tuscany and was born into a very privileged family in Florence that bears the surname Comparetti, ${ }^{7}$ a well known and prestigious surname in the Tuscan city. Milani's father was a University professor, his grandfather an archaeologist of repute and his great grandfather an internationally renowned philologist. Although he shared with Freire the experience of being raised in a predominantly Catholic country, Milani was certainly not religiously influenced by his parents. His mother declared herself an atheist in a 1970 interview $^{8}$ and a footnote on the website, where this interview is reproduced, points out that she often referred to herself as agnostic. Milani's parents went through the motions of marrying through the Catholic Church but that was only because they were Jews and feared persecution from the Fascist government of the time. Surrounded by books, archaeological artefacts and leading intellectuals, as well as the wealth of the rentier classes, Milani was endowed with a cultural capital to which his schooling, during the Fascist period, could not appeal. Like Freire, he too had his mortifying moments as a child such as when he was pulled up by a woman for eating white bread in an alley inhabited by poor people, a social marker which must have made him aware of the social differences prevalent at the time, or when he would ask the family chauffer to drop him off at some distance from school, lest his school companions would see him being afforded such luxurious treatment ${ }^{9}$ in a city 
where there were only about fifteen private cars available, two of which were owned by Lorenzo's father (Fallaci, 1993, pp.13, 14).

Milani had a very independent mind and he defied his family's aspirations for him by joining an art academy instead of a university. ${ }^{10}$ Nevertheless his family background gave him the confidence to speak his own mind, to be a livewire on which nobody could thread, and he developed the reputation of being a maverick and someone who does not suffer fools gladly. It was probably through painting that he drew closer to the Catholic faith. He developed a profound interest in religious art and engaged in research on liturgy and colour so that he could capture the paintings' iconic significance. Much to his mother's chagrin, he eventually decided to receive holy confirmation and, years later, joined the seminary, eventually being ordained in 1947. Congratulated by Lorenzo's wet nurse, whose son was also ordained a priest, Lorenzo's mother -Alice Weiss - exclaimed "bad milk" (Fallaci, 1993, p. 27), an indication of her feelings towards the priesthood and the Catholic faith in general, despite her profound love for her son which was reciprocated by Lorenzo throughout his short life.

Milani's priesthood continued to bring him in close contact with poor people and his feelings of solidarity with the oppressed (the poor and powerless) continued to be strengthened by his reading of the gospels and his clinging to an image of Christ whose option was for the poor - the meek who should inherit the earth. After a short spell at Montespertoli, he moved to the mainly working class and peasant inhabited San Donato di Calenzano where he led an evening 'popular school' (scuola popolare) for adults, which, he insisted, had to be devoid of all religious symbols ${ }^{11}$ to attract people of different political persuasions (Simeone, 1996, p. 99). Conversion was regarded by 
Milani as an act of grace and not something that can be taught. (ibid.) He did not believe in the idea of a denominational school (scuola confessionale) which would have sharpened the social divisions in post-war Italy (ibid.). ${ }^{12}$ There was a strong secular feeling about his school which was not well received by the ecclesiastical authorities. His classes dealt with a range of subjects many of which related to class politics and oppression. Invited speakers were challenged by the course participants who were encouraged to prepare the topic beforehand, throughout the entire week, and engage in dialogue and a participatory approach. This and his own unorthodox approach to religion and pastoral work proved too much for sections of the San Donato community and certain priests based in the area. He was 'transferred', or 'exiled' if you will, to an obscure locality (Sant'Andrea a Barbiana), in the Mugello region, lacking very basic infrastructural amenities; the only road leading to the village came to an end a kilometre away. It was there that Milani developed his best known educational project, a full time school for 'drop outs' of the public school system and developed an alternative radical pedagogy that has been a source of inspiration to teachers and social activists in Italy and elsewhere ever since. This was also the period when he wrote his controversial book (Esperienze Pastorali - Pastoral Experiences) and co-wrote, with his students, a series of letters including the famous Lettera and the letters in his defence of the right to conscientious objection to military conscription. He co-wrote many of these letters and taught, as well as administered the parish, while suffering from Hodgkin's disease which claimed his life at the age of 44 .

\section{Any influence of one on the other?}


It is most unlikely that Freire had any influence on Milani given that the latter died in 1967. There are, however, striking similarities in some of their pedagogical approaches and their underlying concern: a concern for the underprivileged, the oppressed in Freire's language and 'I Gianni bocciati' (the failed Giannis) in the language of the Lettera written, under Lorenzo's direction, by eight pupils from the School of Barbiana who would each be considered a 'Gianni'. It is plausible that Paulo Freire would have been exposed to the name and legacy of Don Milani and the School of Barbiana during the time when he worked in Geneva for the World Council of Churches. It is possible that Freire came across such a legacy during his meetings with Italian workers, trade unionists and educators both in Geneva and Italy itself. Milani had already been enjoying an influence throughout Italy at the time, following the publication of Esperienze Pastorali and the Lettera, the latter in 1967, the year of his death. The Lettera had some influence on the sessantotto ('68) movement in Italy and the strong Cattolici di sinistra (Catholics on the left $)^{13}$ movement that continues to make its presence felt throughout the peninsula. Nevertheless, we find virtually no references to Milani and the School of Barbiana in Freire's widely published work in English,

\section{Underlying common influence: Radical Christianity}

It is clear from the above biographical accounts that both educators were Christian- inspired. In Freire's case, the Christian precepts in his writings derive from a variety of sources notably the radical Catholic tradition in Brazil (De Kadt 1970), the Christian personalism theory of Emanuel Mounier and the Brazilian, Christian de Atiade and other figures connected with the Liberation Theology tradition by which he was influenced and on which he himself exerted an influence. Cardinal Paulo Evaristo Arns 
told the present author and a colleague (Carmel Borg) at the São Paulo Cathedral in April, 1998 that Freire changed not only people's lives but also the church, with reference to the 1968 Episcopal Conference in Medellin (Mayo, 2004, p.6). Freire very much belonged to the 'prophetic church' which he contrasts with the 'traditional' and 'modernising' churches (Freire, 1985, p. 137), the latter constituting, according to Cornell West, the 'Constantinian Church' in short the church which is very much part of the empire. But Christianity constitutes just one main strand in Freire's thinking. There is however another important influence on Freire, notably that of Marxism, comprising the work of Marx himself. As a matter of fact, any account of the influences on Freire's work would be incomplete without some discussion concerning the Marxian concept of ideology, and therefore Marx’s theory of consciousness (Allman, 1999; Allman 2001). The style in which Pedagogy of the Oppressed is written is very much the dialectical one adopted by Marx (Allman, 1988, 1999). Freire draws on a wide range of early writings by Marx and Engels, notably The German Ideology, The Economic and Philosophic Manuscripts of 1844, the Theses on Feuerbach and The Holy Family. Other writings by Marx and Engels, however, feature prominently in such works as Pedagogy in Process (Freire, 1978) where Freire attempts to come to grips with the social relations of production in a former Portuguese African colony (Guinea Bissau) that had just achieved its independence. In this work, and precisely in letter 11, Freire adopts Marx's notion of a 'polytechnic education' (Castles and Wustenberg, 1979; Livingstone, 1983), ${ }^{14}$ advocating the forging of a strong relationship between education and production (Freire, 1978). ${ }^{15}$

There is also the influence of Gramsci's elaboration of the concept of hegemony (Allman, 1999; Mayo, 1999), given that Freire claims to have been influenced by 
Gramsci when in Chile after Marcela Gajardo shared with him a copy of the anthology of Gramscian writings (in Spanish translation, of course), Letteratura e vita nazionale (Literature and National Life) (Morrow and Torres, 1995). One can argue therefore that there are two main strands in Freire's thinking, especially as expressed in his best known work, Pedagogy of the Oppressed (Freire, 1993): Christianity and Marxism.

Milani is likewise eclectic in his writing and draws from various sources but the underlying source in his work is that of Christianity with the main impetus deriving from the Gospels. While Marxist writers must have appealed to Milani and he certainly used Gramsci's Letters from Prison as one of the reading texts at the School of Barbiana, ${ }^{16}$ there is no evidence of Marxist thinking serving as an important underlying current in his writings. The Lettera, written under his direction, is devoid of the sort of theoretical references one finds in, for instance, Pedagogy of the Oppressed. It is less erudite in this regard but no less powerful in the force of its argument. Milani's attitude towards socialism is somewhat ambivalent. He criticised the Italian Communist Party (PCI) and the Catholic Church for vying with each other and, consequently, selling young working class people short in the various Italian localities with which he was familiar. In his view, they placed more emphasis on entertainment, such as carnival balls (Milani, 2004), than on education, with a view to swelling membership in the PCI's case or winning over souls in the case of the Catholic Church. Milani was not averse to socialism as an ideology per se, despite his occasional reference to the excesses of the so-called 'socialismo reale' (actually existing socialism) in the Soviet Union and the rest of the Eastern Bloc (Freire was equally critical of such excesses). In fact, Milani is on record as saying that democracy and socialism are "the two noblest political systems mankind has 
yet been given" (Milani, 1988a, p.25) and he considered socialism "the highest attempt of humankind to give, already on this earth, justice and equality to the poor.” (ibid, p. 26) ${ }^{17}$

Freire, for his part, became a founding member of the socialist oriented Workers' Party (PT) in Brazil and even served as Education Secretary in São Paulo on behalf of the PT. Milani and his pupils, writing in the Lettera, express an almost cynical attitude towards parties in Italy. They do not differentiate between the dominant parties in Italian political life, the "partiti dei laureati" (Graduates' political parties) which allow representatives of the dominant social classes to legislate on behalf of the poor. "But first we have to get into Parliament. Whites will never make the laws needed by the blacks." (School of Barbiana, 1969, p. 53). ${ }^{18}$ The assumption here is that even those parties that ostensibly represent the interests of the working class, the socialist and communist parties, are the preserve of the most influential families and the ruling class in Italian society. Of course, the thinking on this subject is conditioned by the particular situation obtaining in the Italian context, a situation in which members of the same family (e.g. the influential Berlinguer-Segni-Cossiga family from Sassari) can occupy leadership positions on different sides of the national political spectrum. They also mention the mechanism whereby working class and peasant class people who make it through the system, against the odds, and enter parliament are often 'embourgeoised' in the process. Milani's dreamt not of the 'liberation' of people from farming but of a liberated farmer content with living a sober life. ${ }^{19}$

These context-conditioned differences notwithstanding, there is something that strongly connects Milani's ideas concerning society and education to those espoused by Freire, namely an underlying option for the oppressed and a commitment to an education 
for social justice. Theirs was a vision steeped in modernity and its concomitant notion of an emancipatory education. They both believed in a world not as it is now but as it can and should be.

\section{Education for social justice}

Paulo Freire will be always identified by educators for his pedagogy of the oppressed. He has helped educators develop sensitivity to the politics of knowledge and to confront a very disturbing question: on whose side am I when I teach/act? "Educators must ask themselves for whom and on whose behalf they are working." (Freire, 1985, p. 80) Education, for Freire, is not neutral and involves educating for either domestication or liberation. It involves taking sides. Being neutral meant, for Freire, that one is siding with the dominant. The same applies to Milani who, in his Letter to the Military Chaplains, states forcefully:

If you persist in claiming the right to divide the world into Italians and foreigners, then I must say to you that, in your view of things, I have no Fatherland. I would then want the right to divide the world into disinherited and oppressed on one side, and privileged and oppressors on the other. One group is my Fatherland; to me the others are foreigners. (Milani, 1988a, p. 19) ${ }^{20}$

In the words of one of his former students, Edoardo Martinelli (one of the eight authors of the Lettera), "There was obviously nothing really neutral about Don Milani. He believed in a committed educator, one who takes sides: 'Better a fascist than indifferent!' " ${ }^{21}$ Echoing Amilcar Cabral, Paulo Freire had argued that the revolutionary activist, and by implication, the revolutionary educator, would have to commit 'class suicide', that is to say renounce his or her former state of privilege to work on the side of and with, not for, the oppressed. To what extent this is possible is quite arguable given the difficulties involved in 'jumping out of one's skin.' It is more likely that one has to 
engage critically and tenaciously with one's contradictory consciousness in these circumstances (Mayo, 1999). Don Lorenzo Milani came close to the idea of a person committing class suicide or, to use Freire's more Christian metaphor, experiencing his Easter. He denounced his own education which reflected his country's imperialistic ambitions:

They presented the Empire to us as a glory for the Fatherland! I was thirteen at the time; it seems as if it were today. I jumped with joy for the Empire. Our teachers neglected to tell us that the Ethiopians were superior to us. We were going to burn down their huts with their women and children inside, while they had done nothing to us.

That was a cowardly school which - wittingly or unwittingly, I cannot say - prepared for us the horrors to follow in three years' time. It prepared millions of obedient soldiers, obedient to the orders of Mussolini. To be more precise, obedient to the orders of Hitler. Fifty million people died. (Milani, 1988b, p. 65) ${ }^{22}$

Denouncing this type of chauvinistic education at the time was no difficult task given that the period of schooling referred to occurred during the Fascist period, much vilified in the post-war years. Milani however went a step further and held the social class to which he belonged responsible for the horrors of the imperialistic wars described earlier (Milani, 1991, p. 42; Milani, 1988b, p. 62; Scuola di Barbiana, 1996, p.74). Despite being a Jew, an ethnic marker which made one ever so liable to persecution by the Fascists at the behest of Hitler, he was also a member of that same bourgeoisie that was responsible for the terrible turn of events in Italian politics (the turn to fascism) to safeguard its privileges and avert its crisis of hegemony. Conscious of the fact that resources were limited and highly suspicious of the emerging consumerism at the time, he chose a life of sobriety, austerity and poverty, a practical renunciation of the life to which he was born and in which he was bred. Once again, Edoardo Martinelli states: "He did not live his sober life as a form of penance, abstinence or simply Christian living but 
as a way of embracing the values and pleasures that can be satisfied and learnt only through poverty." And yet the earlier reference to the 'partiti dei laureati' (Graduates' political parties) would suggest that Milani and the Barbiana students would be among the first to recognise the limits of class suicide. They seem to doubt whether people from wealthy families can, despite their allegiances and ethical commitment to the subaltern classes, 'jump out of their skin' and break away from their 'habitus.'

These contradictions notwithstanding, both Freire and Milani would be agreed on regarding educating as a political act. Both see traditional educational institutions as bourgeois institutions and conventional teaching, marked by what Freire would call 'banking education', as an activity which serves to support the status quo in a society marked by 'cultural invasion' and what Pierre Bourdieu would regard as the 'cultural arbitrary' of the dominant sectors of society. Repetition and ultimately exclusion was the case with the compulsory schooling of students from subaltern social strata in Italy during Milani's time. This was the experience of Gianni from whose point of view the Lettera is written. It is written in a tone of anger that results from the recognition of the 'symbolic violence' meted out by a public school system that serves to reproduce class hierarchies. What is ostensibly a 'fair' public education system, intended to provide opportunities for all citizens, according to the terms of the Constitution, is in effect a subtle way of reproducing the class system on the basis of a contestable notion of 'meritocracy':

The poor man [Gianni's father] - if he knew what was going on I would pick up his weapon and be a Partisan again. There are teachers who coach for money in their free time. So, instead of removing the obstacles they work to deepen the differences among students (School of Barbiana, 1969, p.35) ${ }^{23}$ 
The schooling system, as countless educational sociologists have underlined over the years, backed by endless research, favours the 'cultural capital' of the middle class. In contrast to the figure of Gianni, in the Lettera, we find that of Pierino, the "doctor's son" (ibid, p.25), who enters school with a significant head-start, who finds the scholastic experience a natural extension to the culture of the home, who moves easily through the various grades and who "at nine, finds himself in the class for ten to eleven years olds" (ibid, p.29). Unlike Gianni, whose father "went to work at age twelve and did not finish the fourth year level of schooling" (ibid, p.34), Pierino can afford to have less formal schooling since he can avail himself of the materially rewarding 'cultural capital' derived from home and its surrounding milieu (ibid, p.48). ${ }^{24}$ This is the reason why Milani helped develop a school 'a tempo pieno' (full time) at Barbiana, including weekends. Like Bourdieu and Passeron (1990), the authors of the Lettera state:

You say that little Pierino, daddy's boy, can write well. But, of course, he speaks as you do. He is part of the firm (ibid, p.12). ${ }^{25}$

He too, is already branded, but with the mark of the chosen race (ibid, p.25)

While Freire must have felt the same way about formal schooling, he was also aware of the fact that, in his native Brazil, very few pupils had access to public education where the 'drop out' rate after one or two years was alarming: 8 million children of school age in Brazil failing to spend a single day at school with 6 million of those who enter being "expelled" (the term 'drop-out' is a misnomer for Freire) after the first or second year. In São Paulo, where he carried out his reforms, 800, 000 to 1, 000,000 children lived on the streets. (Freire, in Morgagni, 1995, p. 87). Freire would underline the non popular and therefore socially discriminating nature of schools by the fact that they were perceived as 'not ours' by the popular classes who often waged violence 
against the institution. The perpetration of violent acts against the school often resulted in the institution setting up barriers and adopting tougher security measures that continued to isolate it further from the community it intended to serve, rendering it a veritable fortress. (see Gadotti, Freire and Guimarães, 1995, pp.58-60). This situation is not unlike that reported by Giroux (2006, p. 97) with respect to public schools in the USA in the context of a 'carceral state' and increasing militarisation on the foreign and home fronts.

Freire quotes an ex-prisoner who stated on TV that, while everyone discussed the violence that he and others committed, nobody discussed the violence they suffered (Freire, in Gadotti, Freire and Guimarães, 1995, p. 59), the reference here being to the 'symbolic violence' perpetrated by institutions such as schools on the working class. Freire goes on to state that it is necessary to research the motives for the violence being perpetrated against schools and also research the school's significance for the community, given that community members react violently toward it.

While Freire has stated time and time again that we should not romanticize education and accord it powers it does not have, he still believed in agency and in the potential for education to serve a democratic and liberating purpose. Unlike radical contemporaries such as Illich, he saw schools as sites of contestation and it is for this reason that, when he was in his late sixties, he and his team took on the onerous task of reforming the public school sector in São Paulo with a view to turning public schools into places that appeal and belong to the traditionally socially marginalised classes rather than places that are perceived as being antagonistic towards these same classes. The school was intended to constitute a key institution in the development of a truly democratic and popular 'public sphere', the term being used in Habermas' sense. He introduced the 
notion of a 'popular public' school which incorporated some of the principles associated with the type of popular education with which he is associated. This was a community school not unlike that developed by Milani and his students from Barbiana and the surrounding areas. Freire and Milani seem to be in agreement on one very important issue namely that a liberating and democratic education belongs to not the world of 'having' but the world of 'being'. They also concur that there is no method and there are no techniques involved in providing this alternative type of education. Freire reiterated this point time and time again, rejecting what has come to be regarded as the 'fetish of method' (see Aronowitz, 1993, Macedo, 1994, Macedo in Freire and Macedo, 1995, Allman, 1996). Milani responded, when asked the irritating question regarding what was the success of his approach at the adult education classes in San Donato, with the following statement, written in his controversial Esperienze Pastorali:

They ask the wrong question. They should not be preoccupied with what one has to do to teach but with how one should be in order to teach. (My translation from Milani, 1996, p. 80). ${ }^{26}$

In Milani's view, teaching and learning involved 'being,' rather than 'how to do." 'Being' (Essere) entailed having clear ideas about social and political issues (ibid), the mark of those who educate for a critical citizenship. Both are in agreement that, to use Freire's words, experiments cannot be transplanted but must be reinvented. Milani was adamant that the Barbiana experience could not be reproduced elsewhere. It was an experience related to place and context. Freire always spoke about the need to reinvent the political pedagogical approach he promoted and not try to apply it in cargo-cult style. In short, the Barbiana and Freirean experiments served as sources of inspiration and as 
means to stimulate the imagination of those who tend to educate for a world not as it is now but as it should and can be - stimulate and inspire, yes but not transplant.

Furthermore, both related education to life, in this respect echoing Dewey with his emphasis on education and experience (Dewey, 1938). They argued for an education that had to be culturally relevant and not culturally alienating as was the hallmark of the traditional school that bored the life out of working class children. In the words of Edoardo Martinelli:

The schooling of that period - I would dare say that the same could well apply to contemporary schooling - was based on the strict transmission of ministerial programs. These programs were carried out 'to the letter' with the teacher being allowed little autonomy. Everything was planned to the extent that we students (there were several of us around, with different backgrounds) could anticipate the events, the questions and the title of the subjects to be tackled. We hardly came across anything that was unexpected and there were no situations that led to the adoption of pedagogical strategies that automatically connected with our interests, motivations and environments. The agenda was the same year in year out. I recall that I struggled to cope at school and I hated almost every subject.

I could not perceive, at the time, the connection between learning and life. When I arrived at Barbiana, everything was different. The point of reference for the group's learning was life itself and this entailed an active research process. The learning setting itself was dynamic. ${ }^{27}$

Foreign language teaching and acquisition constitutes one example of the manner

in which Milani insisted on relating learning to life. He sent his pupils abroad to work in various cities and earn enough for their upkeep while they resided there. ${ }^{28}$ This was intended for them not simply to cross borders and broaden their horizons but also to learn foreign languages as spoken by the native speakers themselves. This approach stood in marked contrast to the artificial way by which foreign languages were taught and examined in the Italian public school system. Working and peasant class students often failed tests, the contents of which had no bearing on the kind of life lived within and outside the student's own region. As the authors of the Lettera say, the French learnt by 
Pierino, which enabled him to pass the state exam, would not allow him to find the way to the toilet in France (Scuola di Barbiana, 1996, p. 21).

In keeping with the Marxist tradition, Freire regards one's material surroundings as the basis for the development of one's consciousness. In the words of Marx and Engels, "Consciousness is, therefore, from the beginning a social product, and remains so as long as men (sic.) exist at all." (Marx and Engels,1970, p.51). Freire's process of education based on 'Cultural action' is concerned with the relationship between knowledge and one's material existence. For Freire, the starting point is always that of human beings "in the 'here and now'", that is to say, the human beings' current situation "from which they emerge, and in which they intervene."(Freire, 1993, p. 85). It is for this reason that, in his adult education work, members of the cultural circles researched the community, analysing its issues and codifying them. It is also for this reason that teachers from the schools that elected to join his 'popular public' schools project in São Paulo researched the community to derive the generative themes. These generative themes are conceived of, in the words of O'Cadiz, Wong and Torres, as “the building blocks for the construction of a locally relevant curriculum." (O'Cadiz et al, 1998, p. 85). Likewise Milani used events or developments within the community that captured the students' imagination and used them as motivating factors for lessons in a variety of areas. Martinelli discloses that, when he entered the classroom at Barbiana, he saw Don Milani and the rest of the class analyse skeletons in what was an anatomy lesson.

The immediate motive, the key point of departure for his pedagogical activity, was provided by the fact that the floor of the society, which stood adjacent to the church, caved in. Bones were discovered as a result. The more profound and long term motive, as he explained in the letter to the Judges, with reference to his pedagogical practice, was to avail himself of this particular event to capture the pupils' interest and thus gradually lead them, once they had become so motivated, 
to tackle the core areas of the disciplines. A few bones were sufficient to enable one to learn how to use vocabulary and texts dealing with anatomy and physiology. These subjects were non-existent in the middle schools of the period. This is how we learnt to read, write and count. ${ }^{29}$

The operative word here is 'lead' for the 'here and now' constituted only the starting point of the lesson and was meant to lead to the disciplines. The same applies to Freire for whom the "Educands' concrete localization is the point of departure for the knowledge they create of the world" (Freire, 1994, p.85). Once again, it is the starting point, however, and not the be all and end all of the pedagogical encounter. (See Freire, 1994, p.84). In Dewey's words, "But finding the material for learning within experience is only the first step. The next step is the progressive development of what is already experienced into a fuller and richer and also more organized form, a form that gradually approximates that in which subject-matter is presented to the skilled mature person." (Dewey, 1938, pp.73-74).

In remaining there and not moving beyond (through co-investigation of the object of inquiry), and therefore not engaging in praxis (obtaining a critical distance from one's world of action to reflect on it for transformative action), one would be engaging in "basism", the romanticization (or "mythification") of the vernacular. (ibid.) O' Cadiz et al (1988) also point out, in their analysis of the school reforms in São Paulo carried out by the Freire-led Education Secretariat, that the generative themes, researched by teachers and other community members, provide only an "initial" step in engaging students and teachers in a critical reading of their world (p. 87).

From Freire's perspective, the best way to engage the learner's framework of relevance is to allow space for the learners themselves to engage critically with the issues, to bring their own insights, culture and different aspects of their multiple 
subjectivities to bear on the learning process. This is the antithesis of 'banking education' and the ministerial programmes to which Martinelli refers. It is for this reason that Freire underlines the importance of 'authentic dialogue' as the key to a truly liberating education, one through which the dialectical relationship of opposites between dominating teacher and submissive student, and therefore between oppressor and oppressed, is transformed. Although stressing that both competent teacher and student are never on an equal footing and that one must distinguish between having authority (bestowed on the teacher by the student who recognises the teacher's competence in the area and as a pedagogue and has faith in the teacher), and being authoritarian, Freire recognises possibilities for critical consciousness in a learning setting where the learners are encouraged to participate through dialogue. It is a situation where the educators are disposed, through humility and love, to relearn that which they think they already know through interaction with the learners. The latter have the potential, as a result of their own studies, preparation and different social locations (these can result in different perspectives on the matter at issue), to re-educate the educator, in the sense employed by Marx in the 'Third Thesis on Feuerbach,' as well as fellow learners in a process of development of 'group knowledge' (Mannheim, 1936, p. 29). We therefore have teacherstudent and students-teachers who regard knowledge as not static but dynamic, an object of co-investigation.

This should serve to provide students with the impetus to learn and 'become more', that is to say, to develop greater coherence, as Freire wrote in his later work (Freire, 1997), using a less essentialist phrase than his earlier one of persons 'becoming more fully human.' (Freire, 1993) This process of learning serves as an antidote to the 
kind of boring and alienating education associated with the 'banking' type of education, the kind of education which led the Giannis or Giannas to be pushed out of the public schools in Italy after they failed their summative exam. Milani too believed in dialogue and the conferenza del venerdi (the Friday conference) at San Donato provided an excellent example of this approach. Workers and peasants prepared the material beforehand to avoid being ostensibly 'passive' listeners (as Freire and others have shown one is never really a passive listener since one derives different meanings from what is being presented without necessarily giving voice to this meaning). They were encouraged to engage the speaker and Milani often pulled up the speaker for a lack of adequate preparation and communication, as is evident from a letter to a certain Dott. Gozzini (Milani, 1970, p. 37).

Milani formalised the students-teachers role at Barbiana for logistical as well as pedagogical reasons. He introduced peer tutoring/teaching realising that pupils often learn better from their own peers with whom they share the same social class and broader cultural background and therefore language. ${ }^{30}$ In a school which placed the emphasis on caring, with the motto 'I Care' written on one of the school walls in English (Milani, 1991, p. 34; Milani, 1988b, p. 56), the students engaged in a pedagogical experience in which they were both teachers and learners. Milani himself tutored the first group of students. As students increased in number - there were around forty students in one particular summer - he adopted peer tutoring as a key pedagogical tool. The older students, while learning from Milani and other students of more or less the same age, also taught the younger ones. 
There was just one copy of each book. The boys would pile up around it. It was hard to notice that one of them was a bit older and was teaching. The oldest of these teachers was sixteen. The youngest was twelve, and filled me with admiration. I made up my mind from the start that I, too, was going to teach. (School of Barbiana, 1969, p. 8) (1 $^{31}$

Older students could spend a whole morning teaching their younger counterparts.

The next year I was a teacher, that is, three half-days a week. I taught Geography, Mathematics and French to the first intermediate year (School of Barbiana, 1969, p.9)

Here was a 'caring' educational relationship based on learning not for one to 'have' (possessive knowledge and individualism) but to 'be' and to 'be' for others, to adopt Eric Fromm's distinction. It must have served as a tremendous source of motivation for the students, once degraded and therefore demoralised by the public schools, to now be 'elevated' to the status of and esteemed as teachers. It is hardly surprising that they would exclaim, in the Lettera, with reference to the long periods of time spent at school and its extended learning setting, "School will always be better than cow shit" (School of Barbiana, 1969, p. 9; Scuola di Barbiana, 1996, p. 13). ${ }^{32}$ This source of motivation made them serve as educators as well as learners (gladly will they teach and gladly will they learn, as Chaucer wrote about the Clerk in the Canterbury Tales) in the same way that cultural circle members, as presented by Freire, served this dual role through a process of authentic dialogue: students-teachers and teacher -student.

An authentic dialogical approach necessitates the sharpening of listening skills. To engage in dialogue, educators must stop suffering from ‘narration sickness' (Freire, 1993, p.71) and become 'listeners'. One would find instructive Freire's illuminating reflection on the notion of 'listening', in Pedagogy of Freedom: 
Listening is an activity that obviously goes beyond mere hearing. To listen, in the context of our discussion here, is a permanent attitude on the part of the subject who is listening, of being open to the word of the other, to the gesture of the other, to the differences of the other. This does not mean, of course, that listening demands that the listener be "reduced" to the other, the speaker. This would not be listening. It would be self-annihilation." (Freire, 1998b, p.107).

Writing on the San Donato experience, in Esperienze Pastorali, Lorenzo Milani states that that he derived many insights and ideas from the peasants themselves:

I owe everything that I know to the young workers and peasants with whom I carried out schooling. It is I who have learnt from them that which they believe to be learning from me. I have only taught them to express themselves while they have taught me to live. It is they who have led me to think those thoughts that are expressed in this book. I have never found them in schoolbooks. I learnt them as I was writing them and I wrote them because they [the workers and peasants] placed them in my heart. (My translation from Milani, 1996, p. 76). ${ }^{33}$

Of course, like Freire, Milani also believed in a directive form of education, the alternative to which would have been laissez faire pedagogy, denounced by Freire. Allowing his students to indulge in laissez faire pedagogy would have been a case of utter irresponsibility on Milani's part, given the age of the students at Barbiana and Milani's concern for their future in a society where knowledge is power. Having said this, he did believe in the students' autonomy as learners. Suffice to mention that when he left San Donato and took up residence in Barbiana, the Friday conference continued to be carried out by the youths of San Donato themselves and he assisted them from afar by establishing contact with potential speakers, as indicated in one of his letters to Elena Brambilla, dated 20/6/1961 (Milani, 1970, pp.147-148). He also had faith in the Barbiana boys' ability to learn on their own by working and living abroad, for a period of time, in places located not only in Europe but also in North Africa.

The emphasis on dialogue and learning from each other both in Freire's cultural circles and in the learning settings which Milani helped create in tandem with community 
members (at San Donato) and his students (at Barbiana) underlines an important aspect of an education intended to serve as an antidote to that which predominates in a capitalist world. Both Milani and Freire underlined the collective dimensions of knowledge. This approach remains relevant in an age when we are bombarded with such phrases as 'selfdirected learning', 'individualised modules' etc. The knowledge promoted by Freire in the dialogical circle was 'group knowledge.' Freire argued that one engages in the task of becoming more fully human not on one's own (it is not an individualistic endeavour) but in solidarity with others (Freire, 1993, pp.85-86). This task, therefore, "cannot unfold in the antagonistic relations between oppressors and oppressed." (ibid). Freire argues, in this context, that, in adopting an individualistic approach to being human, one would be denying others the chance of attaining the same state (i.e. being authentically human). This individualistic endeavour would entail a dehumanizing process of 'having more.' (ibid.)

Like the cultural circle, the School of Barbiana provided a learning space that affirmed the collective dimensions of learning in contrast to the dominant compulsory school that promoted a notion of citizenship predicated on the ideology of competitive individualism so endemic to capitalist social relations. The 'I Care' motto points to this. The programme at Barbiana was based on a politics of solidarity and caring. Not only did pupils care but we have seen how their caring also took the form of a collective pedagogical experience in which they were both teachers and learners. Furthermore, the chronicles of the time served as an important source of learning at Barbiana. The afternoon lesson at Barbiana was common to all. It centred on the facts of the day as reported by the local newspaper. This lesson combined knowledge of current affairs with 
the teaching of such skills as critical analysis and critical literacy, in Paulo Freire's sense of the term. This represents an attempt to read the world through a critical engagement with this world's construction via the media:

I also knew well the history of my own time. That means the daily newspaper, which we always read at Barbiana, aloud, from top to bottom (School of Barbiana, 1969, p.17).

Current events and controversies were followed carefully, articles were engaged with collectively, their underlying ideological positions were identified and unveiled, as Freire would put it, and this exercise in critical literacy often provoked collective responses by the students working in tandem with their mentor. ${ }^{34}$ Echoing a point made by Paul V Taylor in a book on Freire (Taylor, 1993), the Barbiana pupils not only read but also wrote the world and, I would add, they did so collectively and critically.

Perhaps the major contribution to an education with a collective dimension is provided by the following aspect of the teaching/learning process at Barbiana. In keeping with the 'I Care' motto at the school, the class did not proceed to the next stage in the learning process until each and every pupil mastered the last one. Rather than fail pupils, the school gave priority to the child who fell backward. As argued elsewhere (Borg \& Mayo, 2006, p.143), "unlike elitist educational systems which stream and track students according to perceived 'ability,' creating in the process the context for high expectations for largely privileged students (the Pierinos/as) and lower expectations (a 'cooling out' process) and less resources for mostly working class, disabled and non-white students," the Barbiana School accorded pride of place to those who did not keep abreast. The Barbiana School is instructive regarding "how educational institutions, especially those 
run by the Church, can consciously choose to educate the least privileged as part of a genuine option for the poor" (Borg \& Mayo, 2006, p. 143):

But there a boy who had no background, who was slow or lazy (sic), was made to feel like the favourite. He would be treated the way you teachers treat the best student in the class. It seemed as if the school was meant just for him. Until he could be made to understand, the others would not continue (ibid, p.8) ${ }^{35}$ (Sic.)

The Barbiana School favoured an education system that, involving a collective group effort, does not give up easily on the child:

You would wake up at night thinking about him and would try to invent new ways to teach him - ways that would fit his needs. You would go to fetch him from home if he did not show up for class (ibid. p.47). ${ }^{36}$ ( Sic.)

This standpoint provided elements that add credibility and forcefulness to the arguments developed throughout the Lettera. ${ }^{37}$ Certainly teachers play an important role in providing a social justice education predicated on an option for the poor and less privileged members of society. They are not the only important players in this process but nevertheless their role remains crucial. This explains why people who promote a critical approach to education accord a strong sense of agency to socially conscious educators acting as transformative cultural workers (Giroux, 1988) 'in and against' a bourgeoisoriented and therefore biased school system. Teachers play a crucial role within Freire's conception of schools as sites of contestation, although Freire emphasises the importance of teachers having one foot 'tactically' inside and another foot 'strategically' outside the educational system. In the latter case they would be rooted within progressive social movements, the kind of movements Paulo Freire sought to involve, in his educational reforms in São Paulo when he served as Education Secretary.

And it is in the portrayal of teachers that I note an important difference between Freire and Milani or rather, in the latter case, the boys who wrote the Lettera under 
Milani's direction. Despite his portrayal, in a rather mechanistic fashion, of what the teacher does under conditions of 'Banking Education', Freire presents teachers in a very positive light in his written works, especially those written in the latter stages of his life.

He had struggled hard, as Education Secretary, to improve the conditions of teachers:

It is urgent that we drum up more support in this country for public schools that are popular, effective, democratic, and happy and whose teachers are well paid, well trained and in constant development. Never again should teachers' salaries be astronomically lower than those of the presidents and directors of government corporations, as they are today...It is not acceptable on the eve of the new millennium that we continue to experience the alarming quantitative and qualitative deficits that currently exist in our education. We cannot enter the new millennium with thousands of so-called lay teachers, even in the poor areas of the country, sometimes making less than the minimum wage. They are heroic people, giving, loving, intelligent people, but people treated with contempt by national oligarchies. (Freire, 1998a, p. 35)

Furthermore, Freire expressed his concern that the teacher's competence was being undermined through the imposition by a "half a dozen self-proclaimed specialists" of contentoriented "packages" and manuals or guides that describe how to use these packages. (Freire, 1998c, p.67). Freire regards such an imposition of teacher-proof material as indicative of an authoritarian disregard for "the critical capacity of teachers, their knowledge or their practice" (ibid.) and an authoritarian attempt "to instill in teachers a fear of freedom" (Freire, 1998a, p.9). In contrast, Freire not only advocated but helped develop policies, with his Secretariat's team and other stakeholders in education, which enabled teachers to work collaboratively across disciplines to create an interdisciplinary curriculum. (O’Cadiz, et al, 1998, p. 93) In short, teachers were conceived of as people with the ability to reflect on and engage critically with issues and not as technicists executing decisions communicated to them from afar.

One comes across a different portrayal of teachers in the Lettera. These are persons who flunk students, assess them on skills they did not enable the students to acquire (the authors point to the teacher's inane assertion that "writers are born and not made", to which they retort: "Meanwhile 
you receive a salary as a teacher of Italian."- School of Barbiana, 1969, p. $74^{38}$ ) and exacerbate the social divisions between the Giannis and the Pierinos by providing extra tuition to the latter against payment (School of Barbiana, 1969, p. 35). With respect to the last point, they write:

In the morning - during regular school hours - we pay them to give the same schooling to all. Later on in the day they get money from richer people to school their young gentlemen differently. Then, in June, at our expense, they preside at the trial and judge the differences (ibid, p.35)

\section{Lessons from Freire, Milani and the San Donato/Barbiana Experiences}

Did the School of Barbiana give up on teachers in the public school system? On the contrary, the School of Barbiana experience provides an alternative form of schooling from which teachers in the public school system can learn. Much depends on the attitude that the teachers develop, as indicated by Milani when stating that it is more a question of how one must be, rather than what one must do, to be able to teach in a manner that is meaningful to one's students. Teachers can provide such an alternative education by: calling for and engaging in a 'doposcuola' (after school) programme which is provided to everyone and not just those who can pay for it; by encouraging peer tutoring; by enabling students to learn collectively and 'to be' not just for themselves but also and mainly for others; by relating education to life; by starting with the 'here and now' and moving beyond to higher order thinking; by engaging with learners in a critical reading of the world (praxis) as manifest in its day to day reality but also through its construction via the media; by being disposed to learn and relearn what one thinks one already knows from the pupils themselves who have a lot to offer in terms of insights derived from their different cultural backgrounds and specific abilities; by calling for an inclusive curriculum that is relevant to the different pupils in the classroom and a school which 
does not fail students and push them out but ensures that the constitutional right of everyone to enjoy a number of years of public schooling (that does not involve repetition) is respected and safeguarded.

The fact that a number of pupils from the Barbiana experience ended up as teachers indicates that they had faith in the emergence of a type of teacher who was different from the one portrayed in a negative light in the Lettera. They had faith in a teacher concerned with social justice issues and who sees her or his mission in life as one intended to improve the life chances and experiences of those who have traditionally suffered in a socially differentiated system. This is the type of teacher that Freire sought to inspire, a teacher whose attitude and efforts are motivated by feelings of love, humility and social solidarity. And the verb 'calling for' in the list of qualities just provided, a list serving as a brief concluding synthesis of the ideas of Freire, Milani and the Schools of San Donato and Barbiana, indicates that many of the challenges cannot be faced by teachers on their own. As Freire would argue, they can only be faced by teachers within a movement or alliance of movements calling for reforms in the state school system, reforms that would thus help revitalise an important sector of the public sphere.

\section{Notes}

\footnotetext{
${ }^{1}$ I would like to acknowledge the feedback on an earlier draft provided by Dott. Mario Cardona from the Foundation for Educational Services, Malta.

${ }^{2}$ In Britain, the Open University used the Penguin edition of the English version of the Lettera as a text. It featured as a reading text in a course on 'Schooling and Society' (E 202) that started in 1974. I am indebted to Professor Roger Dale of the Universities of Bristol and Auckland for this information. Three years following its publication in Italian in 1967, the text was published in English translation by the US publishing house, Random House. Its North American version was therefore produced during the same year that saw the publication in English of Paulo Freire's Pedagogy of the Oppressed. In 1988, the University of Indiana Press published J.T Burtchaell's A Just War no longer Exists. The Teaching and Trial of Don Lorenzo Milani which includes translated versions of the Lettera ai Giudici (Letter to the Judges), the Lettera ai Cappellani (the Letter to the Military Chaplains) and other material related to the accusations levelled at Milani for his advocacy of conscientious objection to military conscription.

${ }^{3}$ Professor Daniel Schugurensky, an Argentinean scholar at the Ontario Institute for Studies in Education (OISE), University of Toronto, writes with reference to Lettera a Una Professoressa: "I remember reading the Spanish version of the book in the early seventies in my secondary school in Argentina. Needless to say, it was not part of the school
} 
curriculum. My classmate Carlos Vanney lent it to me during a break with an air of secrecy and a mischievous smile, like if he was passing on to me a forbidden and powerful document that was going to change my understanding of schooling. It did. Gracias Carlos!" See Schugurensky's website entitled: History of Education Selected Moments of the $20^{\text {th }}$ Century'

http://fcis.oise.utoronto.ca/ daniel_schugurensky/assignment1/1967barbiana.html

${ }^{4}$ Goulart was a populist who would have been favoured by Freire's literacy programme since more people would have become literate and therefore eligible to vote for him.

5 There are numerous detailed biographical accounts of Freire's life and work. See for instance Taylor (1993), McLaren and Leonard (1993), McLaren and Lankshear (19940, Elias (1994), Gadotti (1994), McLaren (2000), Roberts (2001), Morrow and Torres (2002), Darder (2002), Mayo (1999, 2004), Rossatto (2005).

${ }^{6}$ The biographical account is summarised from information provided by Fallaci (1993), Pecorini (1998) and the Centro Formazione e Ricerca Don Milani, e Scuola di Barbiana, http://www.barbiana.it/biografia.html. Accessed 17 March, 2007. See also http://www.icareancora.it/ Accessed $24^{\text {th }}$ March 2007.

${ }^{7}$ Neera Fallaci refers to Lorenzo as Lorenzo Milani Comparetti (Fallaci, 1993, p. 54). As Domenico Simeone pointed out to me (personal e mail correspondence, 27 November, 2005), Milani always signed his name Lorenzo Milani.

${ }^{8}$ See Fr Nazzareno Fabbretti's interview with Alice Milani Weiss in Il Resto del Carlino, 8 July 1970, reproduced on the website of the Centro Ricerca Don Milani, http://www.barbiana.it/biografia.html. Accessed 18th March 2007.

${ }^{9}$ See 'La Biografia di Don Lorenzo Milani' by the Centro Formazione e Ricerca Don Lorenzo Milani e la Scuola di Barbiana http://www.barbiana.it/biografia.html

${ }^{10}$ A university education would have been taken for granted given that it represented an extension to their life of 'high culture.'

${ }^{11}$ As Domenico Simeone states in his excellent study on Milani's work at San Donato, visiting speakers were surprised and often disturbed by the air of liberty that pervaded the learning environment (Simeone, 1996, p. 99).

12 These were generated by the Church and Communist Party, a situation that was brilliantly satirised by Giovanni Guareschi in his popular Don Camillo-Peppone series.

${ }^{13}$ The term Catcom, short for Cattolico (Catholic) and Communista (Communist), is a popular term in Italy

${ }^{14}$ I am indebted to Professor David W. Livingstone, from the Ontario Institute for Studies in Education/University of Toronto, for this point.

${ }^{15}$ Marx had specifically developed the notion of a 'polytechnic education' in the Geneva Resolution of 1866.

${ }^{16}$ Information obtained from electronic interview carried out with one of the eight former pupils at the School of

Barbiana, Edoardo Martinelli. See Borg and Mayo, 2007 (forthcoming).

${ }^{17}$ See Italian original in Milani, 1991, p. 18.

${ }^{18}$ Scuola di Barbiana, 1996, p. 92.

${ }^{19}$ Electronic interview with Edoardo Martinelli in Borg and Mayo, 2007, forthcoming.

${ }^{20}$ Italian original in Milani, 1991, p. 12.

${ }^{21}$ Interview with Edoardo Martinelli carried out electronically in 2006. See Borg and Mayo, 2007 forthcoming.

${ }^{22}$ Original in Italian in Milani, 1991, p. 4.

${ }^{23}$ Scuola di Barbiana, 1996, p.p. 63, 64.

${ }^{24}$ Fallaci (1993, p. 488) indicates how Milani, when writing about Pierino, had in mind his nephew, Andrea Milani Comparetti, who obtained 10 out of 10 in a History of Art Exam without studying anything. He claimed in a published interview that he obtained the information on the 1400 and 1500 periods from a friend, the evening before the exam. Andrea's friend obtained 6 out of 10 in the exam. In the interview, which Milani read, Andrea states that if the exams were a serious matter then he would not have obtained full marks. It was all a matter of being confident when facing the examiner in what was an oral exam (the Italian educational system involves oral exams). It is all a matter of selling oneself, according to Milani's nephew.

25 ibid, p. 19

${ }^{26}$ The original reads: "Sbagliano domanda, non dovrebbero preoccuparsi di come bisogna fare per fare scuola, ma solo di come bisogna essere per poter far scuola." 
${ }^{27}$ Electronic interview with Edoardo Martinelli in Borg and Mayo, 2007, forthcoming.

${ }^{28} \mathrm{He}$ secured funds for the Barbiana boys to cover their travel expenses. They had to cater for the rest by working abroad.

${ }^{29}$ Electronic interview with Edoardo Martinelli in Borg and Mayo, 2007, forthcoming.

\footnotetext{
${ }^{30}$ It has been argued that one enhances one's learning by communicating what is learnt to others. At the Barbiana school, those who did not keep track were helped to learn by their peers who, in turn, enhanced their own understanding of what was learnt through the effort involved in conveying it to others. "Communicating your ideas to others enables you to clarify and elaborate them" (Bonanno, 2002, p. 97).

${ }^{31}$ Scuola di Barbiana, 1996, p. 12.

${ }^{32}$ Milani was to write with regard to the school schedule: "City people are bewildered by its schedule: twelve hours a day, 365 days a year. Before I arrived, the children kept to the same schedule (and a great deal of fatigue besides) to provide city people with wool and cheese. There was little to be cheerful about." (Milani,1988 b, p. 54)

${ }^{33}$ Original reads: "Devo tutto quello che so ai giovani operai e contadini cui ho fatto scuola. Quello che loro credevano di stare imparando da me, son io che l'ho imparato da loro. Io ho insegnato loro soltanto a esprimersi mentre loro mi hanno insegnato a vivere. Son loro che mi hanno avviato a pensarle cose che sono scritte in questo libro. Sui libri della scuola io non le avevo trovate. Le ho imparate mentre le scrivevo e le ho scritte perche` loro me le avevano messe nel cuore." (Milani, 1996, p. 76)

${ }^{34}$ The same applied to other collective endeavours attesting to their sense of critical literacy This includes the Letter to the Judges in which Milani constantly refers to discussions with his students concerning the many points made throughout the letter, including the several points based on a critical reading of history, one which went against the grain - quite a contrast to the history learnt in the public schools (Scuola di Barbiana, 1996, p. 123).

35 ibid, p. 12.

${ }^{36}$ ibid, p. 82.

${ }^{37}$ The authors warned against streaming practices as suggested by a member of the Christian-Democratic party, who, in a speech in parliament, unabashedly argued that: "Why indeed, should we punish the most gifted children, confining them in a school where they have to clip their wings, adjusting their flight to that of the slower children" (School of Barbiana, 1969, p.40). Alas, many share this view in this day and age, all in keeping with a concept of citizenship characterized by 'survival of the fittest' in a jungle of competitive individualism. Being true to the message of the Gospels, an important source of reading at the Barbiana School, Milani and his students opted for a process of education in which, once again one learns not to have but to be and be for others. Learning was to be shared with others.

${ }^{38}$ Scuola di Barbiana, 1996, p. 125.
}

\section{References}

Allman, P. (1988), Gramsci, Freire and Illich: their contribution to education and socialism. In T. Lovett (Ed.) Radical Adult Education - a Reader, pp.85-113, London: Routledge.

Allman, P. (1994), Paulo Freire's contributions to radical adult education. Studies in the Education of Adults, 26(2) 144-161. 
Allman, P. (1996), Freire with no dilutions. In H. Reno \& M. Witte (Eds.), $37^{\text {th }}$ Annual AERC Proceedings, Tampa: University of Florida.

Allman, P. (1999) Revolutionary Social Transformation: Democratic Hopes, Political Possibilities and Critical Education, Westport, Connecticut and London: Bergin \& Garvey.

Allman, P. (2001). Critical Education Against Global Capitalism. Karl Marx and Revolutionary Critical Education. Westport, Connecticut and London: Bergin \& Garvey.

Bonanno, P. (2002), The Process of Learning. In C. Bezzina, A. Camilleri Grima, D. Purchase \& R. Sultana (Eds), Inside Secondary Schools. A Maltese Reader, Malta: Indigo Books.

Borg, C \& Mayo, P. (2006), Learning and Social Difference. Challenges for Public Education and Critical Pedagogy, Boulder Co: Paradigm.

Borg, C \& Mayo, P. (2007, forthcoming), Public Intellectuals, Radical Democracy and Social Movements. A Book of Interviews, New York: Peter Lang.

Bourdieu, P. \& Passeron, J.C. (1990), Reproduction in Education, Society and Culture (2nd edition), London, Newbury Park and New Delhi: Sage.

Burtchaell, J.T. (Ed.) (1988), A Just War no Longer Exists. The Teaching and Trial of Don Lorenzo Milani, Indiana: University of Notre Dame Press.

Darder, A. (2002), Reinventing Paulo Freire. A Pedagogy of Love, Boulder Colorado: Westview Press.

Dekadt, E. (1970), Catholic Radicals in Brazil, Oxford: Oxford University Press.

Dewey, J. (1938), Experience \& Education. New York: Collier Books.

Elias, J. (1994), Paulo Freire: Pedagogue of Liberation, Florida: Krieger.

Fallaci, N. (1993), Vita del Prete Lorenzo Milani. Dalla parte dell'ultimo, Milan: Biblioteca Universale Rizzoli.

Freire, P. (1993), Pedagogy of the Oppressed (30 ${ }^{\text {th }}$ Anniversary Edition), New York: Continuum.

Freire, P. (1973) Education for Critical Consciousness, New York: Continuum.

Freire, P (1994), Pedagogy of Hope, New York: Continuum. 
Freire, P. (1998a), Teachers as Cultural Workers. Letters to Those who Dare Teach, Boulder: Westview Press.

Freire, P. (1988b), Pedagogy of Freedom. Ethics, Democracy and Civic Courage, Lanham: Rowman \& Littlefield.

Freire, P. (1998c), Politics and Education, Los Angeles: UCLA Latin American Center Publications.

Freire, P \& Macedo, D. (1987), Literacy: Reading the Word and the World, Massachusetts: Bergin \& Garvey.

Freire, P \& Faundez, A (1989), Learning to Question. A Pedagogy of Liberation, Geneva: World Council of Churches.

Gadotti, M.(1994), Reading Paulo Freire. His Life and Work, Albany: SUNY Press.

Gadotti, M., Freire, P.\& Guimarães, S. (1995), Pedagogia: dialogo e conflitto

(B.Bellanova and F.Telleri, F.trans..), Torino: Societa`Editrice Internazionale.

Giroux, H. (1988) Teachers as Intellectuals, Massachusetts: Bergin and Garvey.

Giroux, H. (2006), Stormy Weather. Katrina and the Politics of Disposability, Boulder, Co: Paradigm.

Livingstone, D. W. (1983), Class, Ideologies \& Educational Futures, Sussex: The Falmer Press.

McLaren, P. (2000), Che Guevara, Paulo Freire and the Pedagogy of Revolution, Maryland: Rowman \& Littlefield.

McLaren, P \& Leonard, P. (Eds.) (1993), Paulo Freire: A Critical Encounter, London and New York: Routledge.

McLaren, P \& Lankshear, C. (Eds.) (1994), Politics of Liberation. Paths from Freire, London and New York: Routledge.

Mannheim, K. (1936), Ideology and Utopia (L. Wirth and E. Shils, trans.), New York: Harcourt, Brace \& World Inc.

Mayo, P (1999), Gramsci, Freire and Adult Education. Possibilities for Transformative Action, London \& New York: Zed Books.

Mayo, P. (2004), Liberating Praxis. Paulo Freire's Legacy for Radical Education and Politics, Westport CT: Praeger. 
Milani, L. (1970), Lettere di Don Lorenzo Milani. Priore di Barbiana, Milan: Oscar Mondadori.

Milani, L. (1988a), Letter of Don Lorenzo Milani to the Military Chaplains of Tuscany Who Signed the Communiqué of 11 February 1965. In Burtchaell, J.T. (Ed.), A Just War no Longer Exists. The Teaching and Trial of Don Lorenzo Milani, pp. 18-28, Indiana: University of Notre Dame Press.

Milani, L. (1988b) Milani's Letter to the Judges. In Burtchaell, J.T. (Ed.), A Just War no Longer Exists. The Teaching and Trial of Don Lorenzo Milani, pp. 52-77, Indiana:

University of Notre Dame Press.

Milani, L. (1991), L’Obbedienza Non e`Piu`Una Virtu`, Florence: Libreria Editrice Fiorentina.

Milani, L. (1996), La Parola ai Poveri. Rilettura di Una Esperienza e di Una Testimonianza, Fossano: Editrice Esperienze.

Milani, L. (2004), Una Lezione alla Scuola di Barbiana, Florence: Libreria Editrice Fiorentina.

Morgagni, E. (1995), Anno 1989: Paulo Freire, "dottore in Pedagogia", honoris causa, dell' Alma Mater Studiorum di Bologna. In M. Gadotti, P. Freire \& S. Guimarães, Pedagogia: dialogo e conflitto (B. Bellanova and F. Telleri, Eds.), pp. 86-91, Torino: Societa`Editrice Internazionale.

Morrow, R.A. and Torres, C.A. (1995), Social Theory and Education. A Critique of Theories of Social and Cultural Reproduction, Albany: SUNY Press.

Morrow, R.A. and Torres, C.A. (2002), Reading Freire and Habermas. Critical Pedagogy and Transformative Social Change, New York and London: Teachers College Press.

O'Cadiz, P., Wong, P.L. and Torres, C.A. (1997), Education and Democracy. Paulo Freire, Social Movements and Educational Reform in São Paulo, Boulder: Westview Press.

Rossatto, C.A (2005), Engaging Paulo Freire's Pedagogy of Possibility. From Blind to Transformative Optimism, Lanham: Rowman \& Littlefield.

Roberts, P. (2000), Education, Literacy, and Humanization. Exploring the Work of Paulo Freire, Westport, Connecticut: Bergin \& Garvey. 
Rossatto, C.A (2005), Engaging Paulo Freire's Pedagogy of Possibility. From Blind to Transformative Optimism, Lanham: Rowman \& Littlefield.

Scuola di Barbiana (1996), Lettera a Una Professoressa, Florence: Libreria Editrice Fiorentina.

School of Barbiana, (1969) Letter to a Teacher (N. Rossi and T. Cole, Trans.).

http://www.swaraj.org/shikshantar/LTAT_Final.pdf (accessed 13 November, 2005)

Simeone, D. (1996), Verso la Scuola di Barbiana. L'esperienza pastorale educativa di don Lorenzo Milani a S. Donato di Calenzano, San Pietro in Cariano (Verona): Il Segno dei Gabrielli Editori.

Taylor, P. V. (1993), The Texts of Paulo Freire, Buckingham: Open University Press. 